\title{
Effect of injectable equine collagen type I on metabolic activity and apoptosis of gingival fibroblasts
}

\author{
Sylwia Klewin-Steinböck ${ }^{1}$, Agnieszka Nowak-Terpiłowska², Zygmunt Adamski ${ }^{3}$, Katarzyna Grocholewicz ${ }^{4}$, \\ Marzena Wyganowska-Świątkowska ${ }^{1}$
}

${ }^{1}$ Department of Dental Surgery and Periodontology, Poznan University of Medical Sciences, Poznan, Poland

${ }^{2}$ Department of Biochemistry and Biotechnology, Poznan University of Life Sciences, Poznan, Poland

${ }^{3}$ Department of Dermatology, Poznan University of Medical Sciences, Poznan, Poland

${ }^{4}$ Department of Interdisciplinary Dentistry, Pomeranian Medical University, Szczecin, Poland

Adv Dermatol Allergol 2021; XXXVIII (3): 440-445

DOI: https://doi.org/10.5114/ada.2020.94256

\begin{abstract}
Collagen as a biomaterial is widely used for tissue regeneration due to various advantages including its biodegradation, biocompatibility, and low allergenicity. Along with aesthetic medicine development, collagen is also used in the injectable form as a tissue biostimulator. The area of our study was collagen's impact on fibroblast activity and apoptosis. The research showed that atelocollagen decreases metabolic activity of fibroblasts, but also showed an increasing number of living cells after $48 \mathrm{~h}$ and $72 \mathrm{~h}$ incubation under the influence of collagen.
\end{abstract}

Key words: gingival fibroblasts, equine collagen, cytotoxicity, apoptosis.

\section{Introduction}

Collagen, in various forms, is widely use in surgery and dentistry for blood clotting, healing and tissue remodeling and can be used in aesthetic medicine as a filler and tissue biostimulator. The first experiments with bovine collagen, injected into the skin, were described in the early 1960s. However, the new proposal is using the injectable form of equine collagen which can also be used for gingival biotype changing. It is well known that atelocollagen stimulated fibroblasts produce extracellular matrix, granulation tissue and angiogenic factors and that the proportion between different types of collagen used for stimulation seems to be a key factor [1].

Fibroblasts are cells of mesodermal origin and gingival fibroblasts (GF) just like other fibroblasts from head tissues originate from the neural crest [2-4]. Due to the lack of specific markers enabling in vivo identification, fibroblasts are most often recognized due to the spindle-shaped or triangular, flattened shape with several protrusions, ability to adhere to plastic containers for cell culture and lack of markers for other cell lines [5, 6]. Despite structural and functional similarities fibroblasts are not a homogeneous group of cells. Moreover, the subpopulations of cells were described within the same sample of connective tissue, where also GF show potential to stimulate epithelial growth [2]. Gingival fibroblast can be phenotypically divided into papillary and reticular fibroblasts. Gingival papillae fibroblasts express fetal-like characteristics due to production of migration stimulating factor [7-9]. This heterogeneity is probably responsible for faster healing. The main function of fibroblasts is the production and secretion of collagen, reticulin and elastin fibers and extracellular matrix used to maintain a framework for tissue [2, 5].

Cellular metabolism consists of the chemical reactions that occur in living cells, in which the reactions can generally be divided into catabolic reactions that convert nutrients into energy, and anabolic reactions that lead to the synthesis of larger biomolecules. Apoptosis, also called programmed cell death, is a physiological process which removes unwanted cells. It maintains tissue balance, regulates the pathway of cell growth and proliferation, and eliminates potentially cancerous and virusinfected cells, in opposition to necrosis where cells die due to injury. The apoptotic process is characterized by specific morphologic features such as condensation of the cytoplasm and nucleus, DNA cleavage, and loss of plasma membrane asymmetry [10]. During a lifespan the body must constantly balance cell growth and prolifera-

Address for correspondence: Marzena Wyganowska-Świątkowska, Department of Dental Surgery and Periodontology, Poznan University of Medical Sciences, 70 Bukowska St, 60-820 Poznan, Poland, phone: +48 601883 198, e-mail: marzena.wyganowska@periona.pl Received: 17.12.2019, accepted: 15.01.2020. 
tion with cell death to maintain the equilibrium of tissue. The key control mechanisms of cell growth and death are regulated through cell metabolism [11].

The goal of this study was to observe changes in fibroblasts' metabolic activity and analysis of fibroblast apoptosis after equine collagen type I stimulation.

\section{Material and methods}

\section{Fibroblasts}

The experiment was performed on primary human gingival fibroblasts. The cell culture was established from the tissue samples collected during a standard procedure of covering gingival recessions by a sub-epithelial connective tissue graft in compliance with patients. The bioethics commission approved the study. The positive control (fibroblasts incubated in presence of dimethyl sulfoxide-DMSO) showed $100 \%$ apoptotic cells and the negative control (fibroblasts incubated without added collagen and without DMSO) 73\% apoptotic cells.

\section{Atelocollagen}

The test used collagen material, Linerase, which is a class III medical device in the form of lyophilized type I equine atelocollagen. Equine collagen type I has been used for the last 30 years in dermatology, plastic and vascular surgery for wound healing and skin ulcer therapy. According to information provided by the manufacturer Linerase is obtained and purified without the use of proteolytic enzymes and does not undergo chemical changes in its structure, such as protein denaturation or cross-linking, consequently maintain very high bioactivity. The only chemical change Linerase undergoes is separation of $\mathrm{N}$ - and $\mathrm{C}$-terminal amino acid sequences from the collagen triple helix, to reduce the risk of allergy. Equine collagen has documented effects, stimulating fibroblast proliferation [12, 13].

\section{Cells culture method}

Fibroblasts were grown in $25 \mathrm{~cm}^{2}$ culture vessels containing $4 \mathrm{ml}$ of standard medium (DMEM - Dulbecco's Modified Eagle's Medium, Nutrient Mixture F-12 and a mixture of penicillin, streptomycin, amphotericin) at $37^{\circ} \mathrm{C}$ and $5 \%$ concentration $\mathrm{CO}_{2}$ (New Brunswick S41i, Eppendorf). To passage, the cells were washed with Hank's Balanced Salt Solution to remove residual fetal bovine serum (FBS), which contains a trypsin inhibitor. Then the cells were briefly washed with $0.25 \%$ trypsin solution in $0.53 \mathrm{mM}$ EDTA $(750 \mu \mathrm{l})$. After $10 \mathrm{~min}$ of incubation with trypsin at $37^{\circ} \mathrm{C}$ and a $5 \% \mathrm{CO}_{2}$ atm, the degree of cell detachment (scattering) from the vessel surface was estimated using an inverted microscope (Axiovert 200, Zeiss). To avoid clumping, the cells were mixed by shaking. After detaching the cells from the medium, they were flooded with $8 \mathrm{ml}$ of complete culture medium and poured into two new vessels. Replacement of culture medium with fresh medium occurred every $2-3$ days until the cells reached $80 \%$ confluence.

\section{Metabolic activity assay}

In order to analyze metabolic activity, after achieving the desired level of confluence, cells were transferred to the wells of a 96-well plate in the number of about 5000 per well and incubated for $24 \mathrm{~h}$, after which the medium was replaced with poor (0.5\% FBS) or full $(10 \%$ FBS) culture medium and selected concentrations of collagen were added. Four concentrations of collagen were used in the subsequent research: $0.4 \mathrm{mg} / \mathrm{ml}, 4 \mathrm{mg} / \mathrm{ml}$, $8 \mathrm{mg} / \mathrm{ml}$ and $16 \mathrm{mg} / \mathrm{ml}$. Then the cytotoxicity assay was conducted to determine changes in cell viability. Cell Counting Kit-8 (SIGMA), used in research, is based on reduction of monosodium tetrazolium salt WST-8 (2-(2-methoxy-4-nitrophenyl)-3(4-nitrophenyl)-5-(2,4-disulfophenyl)-2H-tetrazolium) by dehydrogenases in cells to a yellow colored product (formazan), which is soluble in the tissue culture medium. The amount of formazan is directly proportional to the quantity of metabolically active cells. The absorbance was read at $450 \mathrm{~nm}$ in an Infinite M200 PRO plate reader (TECAN) after 24, 48 and $72 \mathrm{~h}$ of incubation.

\section{Cells death assay}

In order to analyze apoptosis, after achieving the desired level of confluence, cells were transferred to the wells of a 6 -well plate in the number of about $10^{5}$ per well and incubated at $37^{\circ} \mathrm{C}$ and $5 \% \mathrm{CO}_{2}$ atm for $24 \mathrm{~h}$. After $24 \mathrm{~h}$ of culture the medium was replaced with fresh medium containing selected concentrations of collagen. Four concentrations of collagen were used in the subsequent research: $0.4 \mathrm{mg} / \mathrm{ml}, 4 \mathrm{mg} / \mathrm{ml}, 8 \mathrm{mg} / \mathrm{ml}$ and $16 \mathrm{mg} / \mathrm{ml}$. In the next step each cellular sample was prepared. $100 \mu$ l of Muse Annexin V \& Dead Cell Reagent was added to $100 \mu \mathrm{l}$ of cell suspension and incubated for $20 \mathrm{~min}$. The research used the Muse Annexin V \& Dead Cell Assay, which allows for quantitative analysis of concentrations of live, early and late apoptotic and dead cells. The Muse assay uses the annexin V affinity to PS (phosphatidylserine), a membrane component normally localized in the internal part of the cell membrane. Early in the apoptotic pathway PS are translocated to the outer surface of the cell membrane where annexin $V$ can bind them.

All research was performed on cells with a low passage number (no higher than 5). Some full confluence trials with a low passage number were frozen in liquid nitrogen for preservation. For this purpose, a procedure was used in which the obtained cell suspensions were centrifuged with bovine serum containing 10\% cryoprotectant (DMSO). 


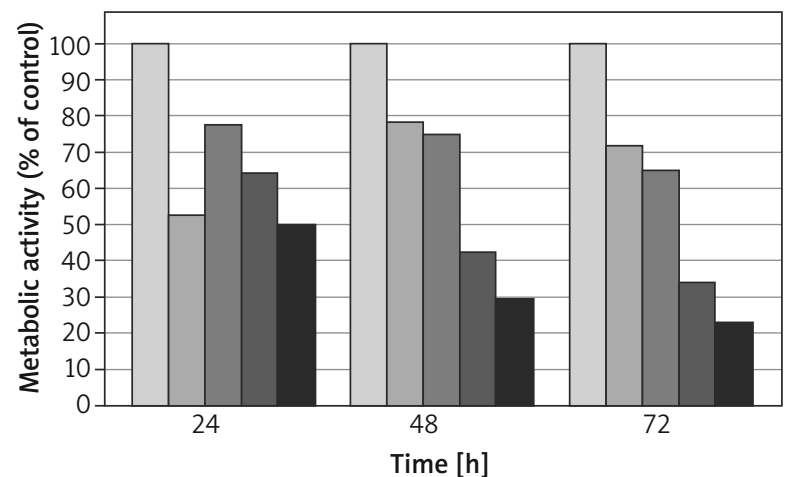

$\square$ Control $\square 0.4 \mathrm{mg} / \mathrm{ml}$ collagen $\square 4 \mathrm{mg} / \mathrm{ml}$ collagen $\square 8 \mathrm{mg} / \mathrm{ml}$ collagen $\boldsymbol{\square} 16 \mathrm{mg} / \mathrm{ml}$ collagen

Figure 1. Analysis of cell metabolic activity (DMEM $+10 \%$ FBS) measured after $24 \mathrm{~h}, 48 \mathrm{~h}$ and $72 \mathrm{~h}$ of incubation of full culture medium with selected collagen concentrations (0.4 mg/ml, $4 \mathrm{mg} / \mathrm{ml}, 8 \mathrm{mg} / \mathrm{ml}$ and $16 \mathrm{mg} / \mathrm{ml})$. Data are expressed as a percentage of the control group

\section{Results}

\section{Fibroblasts' metabolic activity}

Each collagen concentration used in the study caused a decrease of fibroblast metabolic activity compared to the control group regardless of the culture medium used.

From fibroblast samples cultured on full culture medium (10\% FBS) (Figure 1, Table 1) only fibroblasts incubated with $0.4 \mathrm{mg} / \mathrm{ml}$ collagen concentration showed an increase in metabolic activity after 48 and $72 \mathrm{~h}$ compared to $24 \mathrm{~h}$ of incubation (26\% increase after $48 \mathrm{~h}$ and $20 \%$ after $72 \mathrm{~h}$ compared to $24 \mathrm{~h}$ ). Fibroblasts cultured in $4 \mathrm{mg} / \mathrm{ml}$ collagen concentration showed the most stable metabolic activity during the study with a $12 \%$ activity decrease between 24 and $72 \mathrm{~h}$ of cell incubation. Fibro-

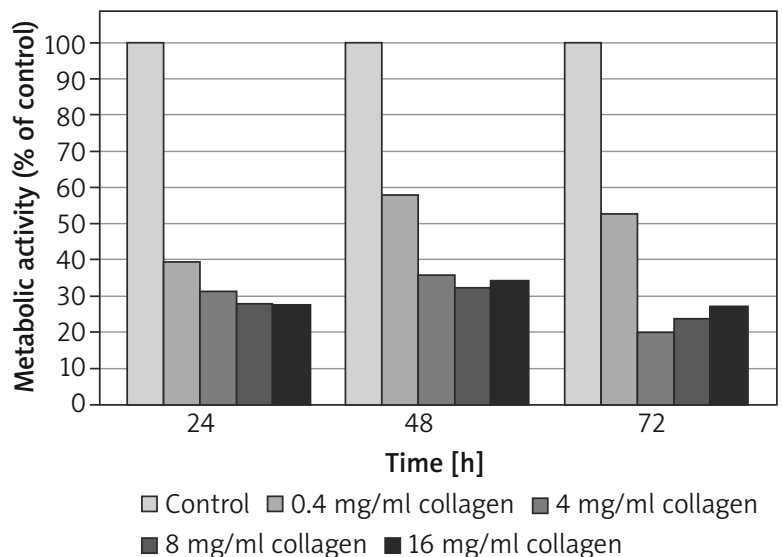

Figure 2. Analysis of cell metabolic activity (DMEM $+0.5 \%$ FSB) measured after $24 \mathrm{~h}, 48 \mathrm{~h}$ and $72 \mathrm{~h}$ of incubation in poor culture medium with selected collagen concentrations $(0.4 \mathrm{mg} / \mathrm{ml}, 4 \mathrm{mg} / \mathrm{ml}, 8 \mathrm{mg} / \mathrm{ml}$ and $16 \mathrm{mg} / \mathrm{ml})$. Data are expressed as a percentage of the control group
Table 1. Percentage results measured after $24 \mathrm{~h}, 48 \mathrm{~h}$ and $72 \mathrm{~h}$ of incubation in full culture medium with selected collagen concentrations $(0.4 \mathrm{mg} / \mathrm{ml}, 4 \mathrm{mg} / \mathrm{ml}, 8 \mathrm{mg} / \mathrm{ml}$ and $16 \mathrm{mg} / \mathrm{ml}$ ). Metabolic activity of control samples is $100 \%$

\begin{tabular}{lcccc}
\hline Time [h] & \multicolumn{4}{c}{ Incubation } \\
\cline { 2 - 5 } & $\begin{array}{c}0.4 \mathrm{mg} / \mathrm{ml} \\
\text { collagen }\end{array}$ & $\begin{array}{c}4 \mathrm{mg} / \mathrm{ml} \\
\text { collagen }\end{array}$ & $\begin{array}{c}8 \mathrm{mg} / \mathrm{ml} \\
\text { collagen }\end{array}$ & $\begin{array}{c}16 \mathrm{mg} / \mathrm{ml} \\
\text { collagen }\end{array}$ \\
\hline 24 & $52 \%$ & $77 \%$ & $64 \%$ & $50 \%$ \\
\hline 48 & $78 \%$ & $75 \%$ & $42 \%$ & $29 \%$ \\
\hline 72 & $72 \%$ & $65 \%$ & $34 \%$ & $23 \%$ \\
\hline
\end{tabular}

blasts cultured with collagen concentration $8 \mathrm{mg} / \mathrm{ml}$ and $16 \mathrm{mg} / \mathrm{ml}$ showed the largest decrease of metabolic activity during the measured period (30\% activity decrease between 24 and $72 \mathrm{~h}$ for $8 \mathrm{mg} / \mathrm{ml}$ and $27 \%$ activity decrease between 24 and $72 \mathrm{~h}$ for $16 \mathrm{mg} / \mathrm{ml}$ ). Fibroblasts cultured with $16 \mathrm{mg} / \mathrm{ml}$ added collagen presented the lowest metabolic activity from all tested samples.

Fibroblasts cultured on poor culture medium (0.5\% FBS) (Figure 2, Table 2) showed lower metabolic activity compared to fibroblasts cultured on full medium. Similarly to previous research fibroblasts incubated with $0.4 \mathrm{mg} / \mathrm{ml}$ collagen concentration showed a bigger increase in metabolic activity after 48 and $72 \mathrm{~h}$ compared to $24 \mathrm{~h}$ of incubation $(18 \%$ increase after $48 \mathrm{~h}$ and $13 \%$ after $72 \mathrm{~h}$ compared to $24 \mathrm{~h}$ ). Fibroblasts cultured with collagen concentrations of $4 \mathrm{mg} / \mathrm{ml}, 8 \mathrm{mg} / \mathrm{ml}$ and $16 \mathrm{mg} / \mathrm{ml}$ showed a slight increase of metabolic activity after $48 \mathrm{~h}(5 \%-4 \mathrm{mg} / \mathrm{ml}, 4 \%-$ $8 \mathrm{mg} / \mathrm{ml}, 6 \%-16 \mathrm{mg} / \mathrm{ml}$ ) and next a decrease in metabolic activity after $72 \mathrm{~h}$ of incubation.

\section{Apoptosis}

Fibroblast groups cultured with $0.4 \mathrm{mg} / \mathrm{ml}$ collagen concentration showed no significant differences in percentage of apoptotic cells compared to the negative control (73\% to $75 \%)$. Other tested samples showed a higher percentage of apoptotic cells compared to the negative control after $24 \mathrm{~h}$ of incubation. Higher collagen concentration in culture medium results in an increase of the number of apoptotic cells compared to the negative con-

Table 2. Percentage results measured after $24 \mathrm{~h}, 48 \mathrm{~h}$ and $72 \mathrm{~h}$ of incubation in poor culture medium with selected collagen concentrations $(0.4 \mathrm{mg} / \mathrm{ml}, 4 \mathrm{mg} / \mathrm{ml}, 8 \mathrm{mg} / \mathrm{ml}$ and $16 \mathrm{mg} / \mathrm{ml})$. Metabolic activity of control samples is $100 \%$

\begin{tabular}{lcccc}
\hline Time [h] & \multicolumn{4}{c}{ Incubation } \\
\cline { 2 - 5 } & $\begin{array}{c}0.4 \mathrm{mg} / \mathrm{ml} \\
\text { collagen }\end{array}$ & $\begin{array}{c}4 \mathrm{mg} / \mathrm{ml} \\
\text { collagen }\end{array}$ & $\begin{array}{c}8 \mathrm{mg} / \mathrm{ml} \\
\text { collagen }\end{array}$ & $\begin{array}{c}16 \mathrm{mg} / \mathrm{ml} \\
\text { collagen }\end{array}$ \\
\hline $24 \mathrm{~h}$ & $40 \%$ & $31 \%$ & $28 \%$ & $28 \%$ \\
\hline $48 \mathrm{~h}$ & $58 \%$ & $36 \%$ & $32 \%$ & $34 \%$ \\
\hline $72 \mathrm{~h}$ & $53 \%$ & $20 \%$ & $24 \%$ & $27 \%$ \\
\hline
\end{tabular}


trol. After $48 \mathrm{~h}$ of incubation the number of apoptotic cells decreased in every tested sample regardless of the collagen amount in the culture medium. The next $24 \mathrm{~h}$ of incubation (72 $\mathrm{h}$ total incubation time) resulted in an increase of the number of apoptotic cells cultured with $0.4 \mathrm{mg} / \mathrm{ml}$ and $4 \mathrm{mg} / \mathrm{ml}$ collagen concentration and a decrease of the number of apoptotic cells cultured with $8 \mathrm{mg} / \mathrm{ml}$ and $16 \mathrm{mg} / \mathrm{ml}$ collagen concentration (Figure 3, Table 3).

\section{Discussion}

Collagen is considered one of the most valuable substances in connective tissue regeneration, because of its biodegradable, hydrophilic and biocompatible character, and it is considered non-immunogenic, and a weak antigen.

Healing and regeneration processes in tissues are successfully supported by enamel matrix derivatives (EMD), plasma components, hyaluronic acid and collagen.

Collagen is the main structural and fibrillar component of gingiva, which accounts for about $60 \%$ of the total tissue protein. Collagen, which plays a fundamental role in tissue repair and wound healing processes, is also an inflammatory process marker. From the superfamily containing fibrillar collagen, which accounts for $90 \%$ of all collagens in the human body and non-fibrillar collagens, type I is the best known and most numerous collagen $[14,15]$.

Its superhelix is usually made up of two identical $\alpha 1$ chains and one $\alpha 2$ chain to form a heterotrimer and is mostly responsible for tissue resistance, stretching and rupture. Type III is a homotrimer and composed of reticular fibers. Collagen III wraps collagen I fibers and is responsible for their proper positioning and tissue elasticity. Collagens types III and I are the main collagenous components in healthy gingiva with a $7: 1$ ratio between types I and III [16]. Physiological levels of tissue stiffness function as a brake on fibroblast proliferation and collagen synthesis [17].

Collagen antigenicity is attributed to the interspecies differences in amino acid sequences located mainly in terminal telopeptides $[18,19]$. In animals, individual collagen triple helices, known as tropocollagen (TC), ultimately lead to the macroscopic fibers and networks observed in tissue, bone, and basement membranes. This telopeptides of TC are important for initiating proper fibrillogenesis and have a second role in stabilizing mature collagen fibrils [20]. Commonly for medical application atelocollagen is used due to lower risk of an allergic reaction. It is type I collagen, which was subjected via the elimination of the telopeptides by pepsin digestion, which are considered to account for most of collagen's antigenicity. Atelocollagen has valuables properties, as solid state at $37^{\circ} \mathrm{C}$ and liquid at $4^{\circ} \mathrm{C}$. The drying process can be controlled to obtain the desired qualities depending on intended use. The most commonly used forms of

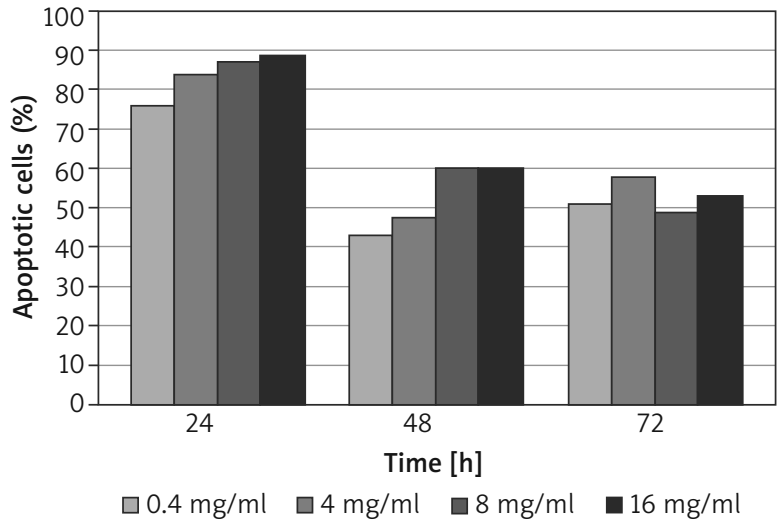

Figure 3. Analysis of changes in cells life after $24 \mathrm{~h}, 48 \mathrm{~h}$ and $72 \mathrm{~h}$ of incubation in full culture medium with selected collagen concentrations $(0.4 \mathrm{mg} / \mathrm{ml}, 4 \mathrm{mg} / \mathrm{ml}, 8 \mathrm{mg} / \mathrm{ml}$ and $16 \mathrm{mg} / \mathrm{ml}$ )

Table 3. Percentage of apoptotic cells after $24 \mathrm{~h}, 48 \mathrm{~h}$ and $72 \mathrm{~h}$ of incubation in full culture medium with selected collagen concentrations $(0.4 \mathrm{mg} / \mathrm{ml}, 4 \mathrm{mg} / \mathrm{ml}, 8 \mathrm{mg} / \mathrm{ml}$ and $16 \mathrm{mg} / \mathrm{ml}$ ). In brackets are the increase and decrease of number of apoptotic cells after 48 and $72 \mathrm{~h}$ incubation time

\begin{tabular}{lcccc}
\hline Time [h] & \multicolumn{4}{c}{ Incubation } \\
\cline { 2 - 5 } & $\mathbf{0 . 4} \mathrm{mg} / \mathrm{ml}$ & $\mathbf{4} \mathrm{mg} / \mathrm{ml}$ & $\mathbf{8 ~ m g} / \mathrm{ml}$ & $16 \mathrm{mg} / \mathrm{ml}$ \\
\hline 24 & $75.13 \%$ & $83.65 \%$ & $86.75 \%$ & $87.75 \%$ \\
\hline 48 & $42.52 \%$ & $47.37 \%$ & $59.47 \%$ & $59.59 \%$ \\
& $(\downarrow 32.61 \%)$ & $(\downarrow 36.28 \%)$ & $(\downarrow 27.28 \%)$ & $(\downarrow 28.16 \%)$ \\
\hline 72 & $50.91 \%$ & $57.23 \%$ & $48.43 \%$ & $52.92 \%$ \\
& $(\uparrow 8.39 \%)$ & $(\uparrow 9.86 \%)$ & $(\downarrow 11.04 \%)$ & $(\downarrow 6.67 \%)$ \\
\hline
\end{tabular}

atelocollagen are water solution, powder, gel, sponge and membrane [18, 21, 22].

Collagen can be obtained from many sources. Very common is bovine-derived collagen. Bovine collagen is readily available and useful for some biomedical purposes, but it suffers from heterogeneity, loss of structural integrity during the isolation process, and potential immunogenicity. Clinical observation revealed that $2-4 \%$ of the population is allergic to bovine type I collagen [18]. Also, the issue regarding bovine spongiform encephalopathy (BSE) caused the search for other sources. The interest was drawn to nonmammalian sources, such as shark and salmon, but fish collagen is more sensitive to heat denaturation compared to bovine collagen [23, 24]. Also in use are porcine and equine-derived collagens. The structure of porcine collagen is similar to human collagen [25].

Cells balance their catabolic and anabolic pathways in order to control their levels of metabolites and ensure that sufficient energy is available as well as monitoring the needs and surpluses of all their different metabolic pathways. They can strengthen a particular pathway by increas- 
ing the amount of a necessary enzyme or use activators to convert that enzyme into an active form. Vice versa, to slow down or stop a pathway, cells can decrease the amount of an enzyme or use inhibitors to make the enzyme inactive.

Up- and down-regulation of metabolic pathways are often a reaction to changes in concentrations of metabolites in the cell and extracellular matrix. Moreover, metabolic products serve as inhibitors of their own synthesis to avoid pathological upregulation in collagen synthesis, which can lead for example to fibrosis. Added atelocollagen can also exhibit those properties. The decrease of metabolic activity observed in the described experiment may be caused by a process known as feedback inhibition. The proof of this thesis can be the fact that higher collagen concentration causes a greater decrease in cell activity. Downregulation of fibroblast activity can also be the result of terminal differentiation and cell elimination.

The test result may be related to culture medium structure. Mechanical properties of matrix play a crucial role in cell behavior. The fibroblast proliferation rate is proportional to collagen concentration, but only when the gel is compressed [17]. A study by Fringer and Grinnell [26] showed that fibroblast DNA synthesis was about twice as high in attached collagen matrices (when collagen matrices remain attached to laboratory dish walls) compared to floating matrices (collagen gel is detached from walls and floats in culture medium). Total protein synthesis and collagen synthesis are low in non-attached matrices. Moreover, cells in a floating matrices change their morphology and switch to quiescence phenotypes and become apoptotic. Research conducted on dermis fibroblast showed that correctly functioning fibroblasts in dermis require appropriate interactions with collagen fibrils, and these interactions cannot be achieved when the fibrils are fragmented [27]. Collagen used in the study was deprived of $\mathrm{N}$ - and $\mathrm{C}$-terminal amino acid sequences to reduce the risk of allergy. The lack of telopeptides can change gel properties or interfere with gel formation. Based on similarities between gingival and dermal fibroblasts, we can assume that lack of fibrillar structure can lead to oxidative stress which in consequence causes a decrease of metabolic activity.

As mentioned previously, culture medium influences cellular properties. With the reduction of nutrient substances cell activity decreases and fibroblasts cultured in poor medium show generally lower metabolic activity compare to cells cultured in full medium.

Results of the apoptotic study can also be related to culture medium structure. Fluck et al. [28] showed in their research that fibroblasts seeded in non-attached matrices undergo apoptosis. The study was conducted on human dermal fibroblasts and showed an apoptosis peak at around 2-4 days of research. Our research showed an apoptotic peak on day 1 , which might be the result of differences between dermal and gingival fibroblasts gingival fibroblasts are more potent, having a higher pro- liferation rate compared to dermal fibroblasts. The higher percentage of living cells in samples incubated with higher collagen concentration is in line with the fact that higher collagen concentration increases fibroblast proliferation. It is difficult to compare our results with others, due to different types of collagen used in research, different types of stimulated cells as well as different time of exposure with different collagen concentration. Song et al. [29] found the viability of fibroblasts in contact with jellyfish collagen much higher ( $146 \pm 5.4 \%$ at day 10$)$ than that of fibroblasts in contact with bovine collagen (112.10 $\pm 7.8 \%$ at day 10 ). Kuzan et al. used the silver carp's collagen in smaller than our concentration and obtained the result that the cytotoxicity of human gingival fibroblasts $(79.93 \pm 16.76 \%)$ decreased with the decreasing concentration [30]. In our research a higher concentration supported gingival fibroblast vitality.

\section{Conclusions}

We conclude that under the conditions of this research atelocollagen did not stimulate metabolic activity of fibroblasts, and atelocollagen showed a tendency to reduce metabolic activity of gingival fibroblasts. One should take into consideration the limited duration (72 h) of the study, depending on laboratory capabilities. So, we cannot predict changes in fibroblasts' metabolic activity in the long term. However, the study of fibroblast apoptosis showed an increasing number of living cells after $48 \mathrm{~h}$ and $72 \mathrm{~h}$ incubation under the influence of collagen. Collagen injection does not decrease tissue stiffness, so we can assume that a higher collagen concentration will support fibroblast proliferation and inhibit apoptosis.

\section{Conflict of interest}

The authors declare no conflict of interest.

\section{References}

1. Goktas S, Dmytryk JJ, McFetridge PS. Biomechanical behavior of oral soft tissues. J Periodont 2011; 82: 1178-86.

2. Häkkinen L, Larjava H, Fournier BPJ. Distinct phenotype and therapeutic potential of gingival fibroblasts. Cytotherapy 2014; 16: 1171-86.

3. Sriram G, Bigliardi PL, Bigliardi-Qi M. Fibroblast heterogeneity and its implication for engineering organotypic skin model in vitro. Eur J Cell Biol 2015; 94: 483-512.

4. Giannopoulou C, Cimasoni G. Functional characteristics of gingival and periodontal ligament fibroblasts. J Dent Res 1996; 75: 895-902.

5. Chang H, Chi JT, Dudoit S, et al. Diversity, topographic differentiation, and positional memory in human fibroblasts. Proc Natl Acad Sci USA 2002; 99: 12877-82.

6. Chang Y, Li H, Guo Z. Mesenchymal stem cell-like properties in fibroblasts. Cell Physiol Biochem 2014; 34: 703-14.

7. Archana A, Srikanth V, Sasireka. Fibroblast heterogeneity in periodontium - a review. Int I Dental Sci Res 2014; 2: 50-4. 
8. Irwin CR, Picardo M, Ellis I, et al. Inter- and intra-site heterogeneity in expression of fetal-like phenotypic characteristics by gingival fibroblasts: potential significance for wound healing. J Cell Sci 1994; 107: 1333-46.

9. Phipps RP, Borrello MA, Blieden TM. Fibroblast heterogeneity in the periodontium and other tissues. J Periodont Res 1997; 32: 159-65.

10. Elmore S. Apoptosis: a review of programed cell death. Toxicol Pathol 2007; 35: 495-516.

11. Mason EF, Rathmell JC. Cell metabolism: an essential link between cell growth and apoptosis. Biochim Biophys Acta 2011; 1813: 645-54.

12. Corbo A, Luci C, Merone G. Skin rejuvenation with equine collagen type 1. Prime 2017; 7: 25-8.

13. Nicer K. Stymulatory tkankowe - jedna kategoria, wiele możliwości terapeutycznych. Dermatol Kosmetol Prakt 2016; 11(44).

14. Czubak KA, Żbikowska HM. Struktura, funkcja i znaczenie biomedyczne kolagenów. Ann Acad Med Siles 2014; 68: 245-54.

15. Ricard-Blum S. The collagen family. Cold Spring Harb Perspect Biol 2011; 3: a004978.

16. Chatoler C, Couble ML, Magilotre H, et al. Connective tissue organization of healthy human gingiva. J Periodont Res 1984; 19: 2211-29.

17. Kanta J. Collagen matrix as a tool in studying fibroblastic cell behavior. Cell Adh Migr 2015; 9: 308-16.

18. Lynn AK, Yannas IV, Bonfield W. Antigenicity and immunogenicity of collagen. J Biomed Mater Res B 2004; 71: 343-54.

19. Lin K, Zhang D, Macedo MH, et al. Advanced collagen-based biomaterials for regenerative biomedicine. Adv Funct Mater 2018; 29: 1804943.

20. Shoulders MD, Raines RT. Collagen structure and stability. Ann Rev Biochem 2009; 78: 929-58.

21. Hanai K, Kojima T, Ota M, et al. Effects of atelocollagen formulation containing oligonucleotide on endothelial permeability. J Drug Deliv 2012; 2012: 245835.

22. Holmes R, Kirk S, Tronci G, et al. influence of telopeptides on the structural and physical properties of polymeric and monomeric acid-soluble type I collagen. Mater Sci Eng C Mater Biol Appl 2017; 77: 823-7.

23. Nagai N, Yunoki S, Suzuki T, et al. Application of cross-linked salmon atelocollagen to scaffold of human periodontal ligament cells. J Biosci Bioeng 2004; 97: 389-94.

24. Avila Rodriguez MI, Rodriguez Barroso LG, Sanchez ML. Collagen: a revive on its sources and potential cosmetic applications. J Cosmet Dermatol 2018; 17: 20-6.

25. Moon SH, Lee YJ, Rhie JW, et al. Comparative study of the effectiveness and safety of porcine and bovine atelocollagen in Asian nasolabial fold correction. J Plast Surg Hand Surg 2015; 49: 147-52.

26. Fringer J, Grinnell F. Fibroblast quiescence in floating or released collagen matrices: Contribution of the ERK signaling pathway and actin cytoskeletal organization. J Biol Chem 2001; 276: 31047-52.

27. Fisher GJ, Quan T, Purohit T, et al. Collagen fragmentation promotes oxidative stress and elevates matrix metalloproteinase-1 in fibroblasts in aged human skin. Am J Pathol 2009; 174: 101-14.

28. Fluck J, Querfeld C, Cremer A, et al. Normal human primary fibroblast undergos apoptosis in three-dimensional contractile collagen gels. J Investig Dermatol 1998; 110: 153-7.

29. Song E, Kim SY, Chun T, Byun HJ, Lee YM. Collagen scaffolds derived from a marine source and their biocompatibility. Biomaterials 2006; 27: 2951-61.
30. Kuzan A, Smulczyńska-Demel A, Chwiłkowska A, et al. An estimation of the biological properties of fish collagen in an experimental in vitro study. Adv Clin Exp Med 2015; 24: 385-92. 